\title{
Interaction of International Sharia Stock Indices, Exchange Rates and Gold Prices against Jakarta Islamic Index (JII)
}

\author{
Muh. Irfandy Azis ${ }^{1}$, Ahmad Juliana ${ }^{2}$, Muhammad Tharmizi Junaid ${ }^{3}$, Tarsyan ${ }^{4}$ \\ Universitas Borneo Tarakan ${ }^{1,2,3,4}$ \\ \{muh.irfandyazis@gmail.com¹, ahmadjuliana75@gmail.com², \\ tharmizi.blenk@gmail.com ${ }^{3}$,tarsyan18@gmail.com ${ }^{4}$ \}
}

\begin{abstract}
The purpose of this study was to determine the long-term, short-term and causal relationship between the World Islamic Stock Index, Exchange Rates and Gold Prices on the Jakarta Islamic Index (JII). The analysis tool used is the Vector Autoregression (VAR) method if the data is stationary at the level. If the data is not stationary at the first difference level, the Vector Error Correction Model (VECM) method is used. The results of the stationary test show that the research data is stationary at the first difference level so it is continued for the VECM model. VECM analysis results in the long term The Dow Jones Islamic Market Index Europe (DJIEU), The US Dow Jones Islamic Market Index (IMUS) and gold prices have a significant negative effect on The JII. The Dow Jones Islamic Market Index Japan (DJIJP) has a significant positive effect on JII. The results of VECM analysis in the short term IMUS index, DJIJP and gold prices have a significant positive effect on JII. The Impulse Response Function (IRF) results show that JII fluctuates with shock to achieve stability. The average time needed to achieve stability is after the 14th period. Then the results of the Forecasting Error of Variance Decomposition (FEVD) analysis starting from the 50th period show that JII has an effect of 96 percent, IMUS affects JII by 3.36 percent, DJIEU 2.72 percent, Gold 0.65 percent, DJIJP 0.10 percent, Exchange rate 0.052 percent and DJIM25 0.028 percent.
\end{abstract}

Keywords: Gold Prices; International Sharia Stock Indices; Jakarta Islamic Index (JII); Exchange Rates; Vector Error Correction Model (VECM)

\section{Introduction}

A country has a capital market that plays ignificant economic position. Good as a means to raise capital, an alternative investment. As in the form of securities, the issuance of debt (bonds), shares and others. The financial market in Indonesia is developing. The development of a country's capital market will be able to improve economic performance and economic fundamentals. To face the current conditions of globalization, where uncertainty is the condition of the global economy. The stock market in Indonesia is growing very well. Marked by the ever-expanding success of the Joining Stock Price Index (CSPI), which demonstrates 
Indonesian capital market overall results. Poor results on other sectoral indices and Islamic stock indexes followed. Indonesia is a country with a Muslim majority population, from some of the world's largest Muslim nations. In improving the financial industry this has been a major opportunity on the stock market. The banking sector is not at odds with Islamic values in this situation. Sharia portfolio holding is part of the sharia financial industry [1].

Tandelilin [2] The purpose of investment is to obtain a return or profit in the future. In addition to getting profits, stock investment also has risks, for this it is necessary to analyze stock performance. To provide an overview of the performance of an Islamic stock price a stock index is formed. An index based on criteria that investors want by the Indonesia Stock Exchange (IDX). There is a concern about the law of halal investing in shares in Indonesia. The Indonesian capital market forms Islamic investment products or instruments. To provide facilities for sharia investment activities. On 3 July 1997 Danareksa Investment Management and Indonesia Stock Exchange (IDX) issued the Danareksa Syariah and Jakarta Islamic Index (JII). With the advent of sharia stock investment goods, the growth of the Islamic capital market in Indonesia is continuing to expand. Such as Islamic mutual funds, Islamic bonds (sukuk). In addition, the establishment of the Sharia Securities List (DES) was later changed to the Indonesian Sharia Stock Index (ISSI) [1]. The number of Indonesian Islamic shares has increased substantially, following the growth of the number over a span of six years, starting in 2014 until 2019.

\begin{tabular}{ccc}
\multicolumn{3}{c}{ Table 1. Sharia Shares in Indonesia } \\
\hline Year & Semi Annual & Amount \\
\hline 2014 & 1 & 322 \\
& 2 & 334 \\
2015 & 1 & 331 \\
& 2 & 331 \\
2016 & 1 & 321 \\
& 2 & 345 \\
2017 & 1 & 368 \\
& 2 & 393 \\
2018 & 1 & 407 \\
& 2 & 420 \\
2019 & 1 & 421 \\
\hline \multicolumn{3}{c}{ Source: Idx.co.id }
\end{tabular}

Table 1 shows the number of Islamic shares on the Indonesia Stock Exchange continues to rise. Table 2 shows the value of Islamic stock capitalization in the Jakarta Islamic Index (JII) index, which was also experiencing growth in the same period.

Table 2. JII Capital

\begin{tabular}{cc}
\hline Year & JII Capital (Billion) \\
\hline 2014 & $1.944 .531,70$ \\
2015 & $1.737 .290,98$ \\
2016 & $2.035 .189,92$ \\
2017 & $2.288 .015,67$ \\
2018 & $2.239 .507,78$ \\
2019 & $2.376 .039,14$ \\
\hline \multicolumn{2}{c}{ Source: Idx.co.id }
\end{tabular}

The Jakarta Islamic Index (JII) is an index that serves as a benchmark for the performance of Indonesia Stock Exchange (IDX) listed sharia shares. The district contains 30 parts of the sharia. 
The most liquid Islamic stocks and the highest market capitalisation are the chosen (Idx.co.id). In figure 1 JII shows fluctuating movements from 2014 - 2019. In 2015 and 2018 they experienced a significant decrease.

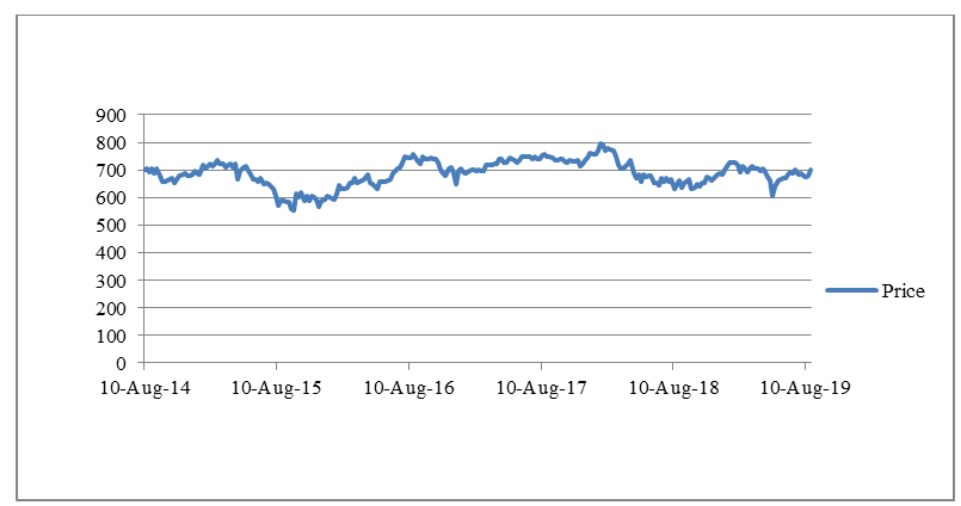

Source: Yahoo.finance.com

Fig. 1. Jakarta Islamic Index (JII) Chart

According to Sudiyatno \& Nuswandhari [3] Stock price movements are not only influenced by internal factors, share prices can also be influenced by external conditions. Instability that occurs by external factors can cause investments to be more risky. Which results in a decline in capital market performance. The external factor of this research is the condition of the movement of international sharia stock indexes from several countries. The index used in the Dow Jones Islamic Business Index (DJIMI) is made up of inventories from different countries. Within this study countries are included the Dow Jones Islamic Market Index Europe (DJIEU), the Dow Jones Islamic Market Index Malaysia Titans 25 (DJIM25), the Dow Jones Islamic Market Index U.S. (IMUS), and the Dow Jones Islamic Market Index Japan (DJIJP). Many of the Islamic stock indices of these countries are comparatively high stock indices, relative to other countries. The following graph shows fluctuating stock prices for sharia in many countries, as well as the JII index.

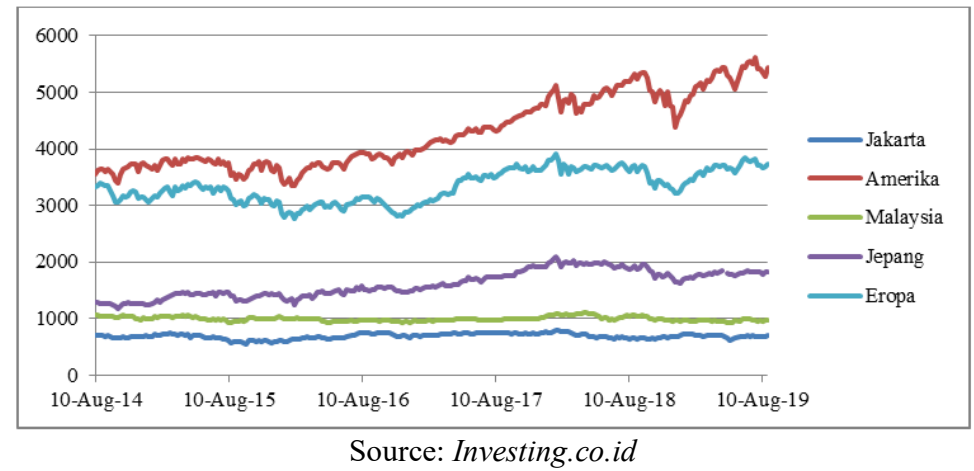

Fig. 2. International Sharia Share Index

Figure 2 shows that the highest Islamic stock index is the US Dow Jones Islamic Market Index (IMUS), then the Dow Jones Islamic Market Europe Index (DJIEU) and the Dow Jones 
Islamic Market Index (DJIJP) and the lowest is the Jakarta Islamic Market Index (JII). And from the graph above it is also known that in October to December 2018 all of these indices experienced a fairly deep decline. Several factors can cause world stock indices to decline. One explanation for this is the outcome of a trade war between the US and China: BBC News 2018[4], and several global countries experiencing a recession, namely Argentina: BBC News September 2018[5]. And Turkey's BBC News March 2019[6].

According to Tan[7] in Haryogo[8], a decline in one of the stock markets such as the Dow Jones index will also affect the stock market in the world. This happens because of the Contagion Effect Theory. Similarly, sharia stock market output will be indirectly influenced by global market turbulence. This is because investors are concerned about the volatility that comes from negative feelings. Within one country market reactions will impact markets in other countries. The Indonesian stock market for sharia is also inseparable from the fluctuating conditions of the rupiah's foreign exchange value (exchange rates) and the gold price.

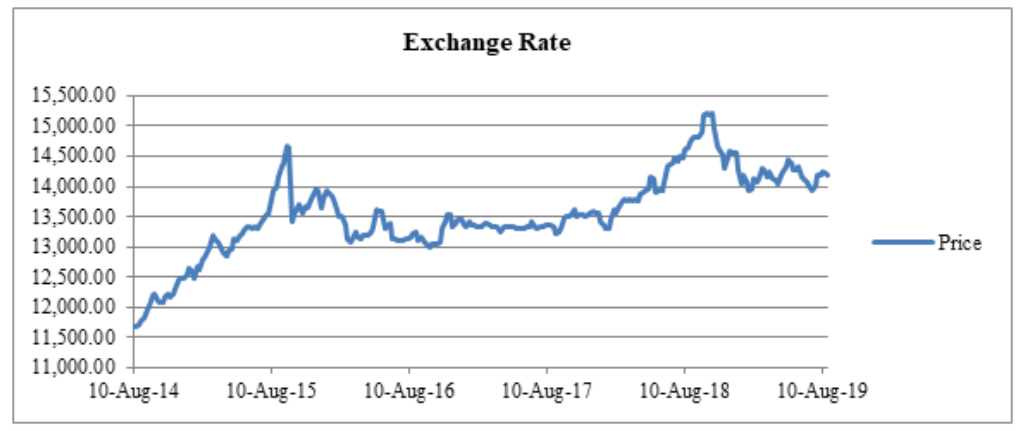

Source: Investing.com

Fig. 3. Exchange Rate

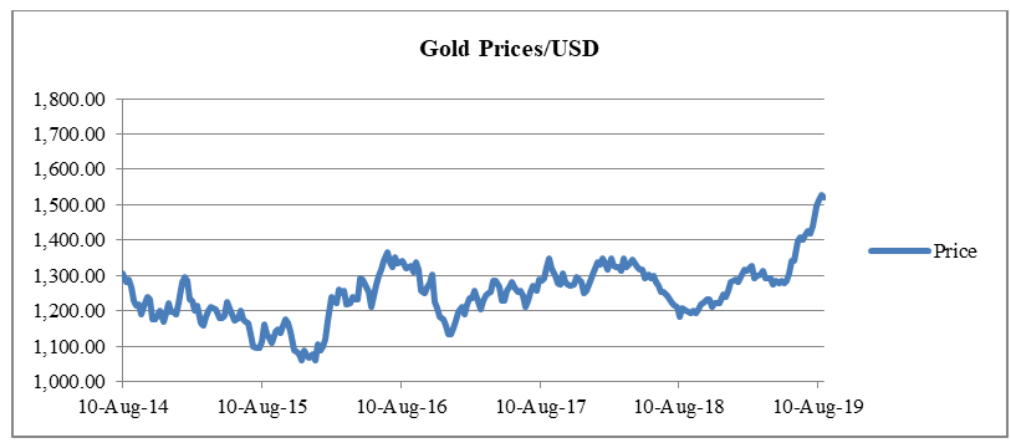

Source: Investing.com

Fig. 4. Gold Prices/USD

Based on Figure 3 and Figure 4, fluctuation of share prices seen in the index is not only influenced by internal factors such as the value of the exchange rate but can also be influenced by market conditions in other countries and the gold prices is also related to the fluctuation of the Jakarta Islamic Index (JII).

Several previous studies have been conducted regarding internal and external factors that affect stock prices. Research by Kuwornu et al. [9], Hussin et al. [10], Beik \& Fatmawati [1], 
Ardana \& Maya [11], the exchange rate has a negative effect on stock prices. This shows that if the exchange rate weakens, investors are likely to withdraw their capital. Then it will move to other countries that have more potential to develop so that capital outflows occur which causes domestic investment to decline. So that the stock price will eventually decline. Because foreign investors (Foreign) quite dominate the capital market in Indonesia in 2019 by $50.64 \%$ and domestic 49.36\%, IDX (2019). Another study, Asmy, et al. [12] showed the opposite result, namely that the relationship between the two variables is positive.

Utoyo \& Riduwan [13], Agestiani \& Sutanto [14], found that the gold price on the Jakarta Islamic Index (JII) has a positive effect. However, Setiawan [15], partially, the World Gold Price Variable has no significant effect on JII. Beik \& Wardana [16], found that the Indonesian capital market with the United States and Malaysia has no long-term relationship. Ardana \& Maya [11], found that the Dow Jones Islamic Market Index Japan (DJIMJP) has a positive and insignificant effect in the short term. The DJIMJP index has a negative and significant effect in the long term. As well as the Dow Jones Islamic Market Index US (DJIMUS) has a positive and significant effect on the Islamic stock index.

Oktaviani [17] concluded that the Dow Jones Islamic Malaysia and Dow Jones Islamic USA variables had a significant influence on the Jakarta Islamic Index (JII). As well as Beik \& Fatmawati [1] where the Dow Jones Islamic Europe index and the Dow Jones Islamic Malaysia index variables against the Jakarta Islamic index (JII) have a significant positive relationship. Based on the previous explanation and the research gap above, this study aims to examine the effect of the International Sharia Stock Price Index, the Exchange Rate and the World Gold Price on the Jakarta Islamic Index (JII). The Islamic stock indexes of several countries in this study are the United State (US), Malaysia, the European Union and Japan.

\section{Methodology}

This analysis will examine the impact of the international index on the JII index, the exchange rate and the gold price. Dow Jones Islamic Market Index Malaysia Titans 25 (DJIM25), the Dow Jones Islamic Market Index Europe (DJIEU), the Dow Jones Islamic Market Index Japan (DJIJP), and the US Dow Jones Islamic Market Index (DJIMUS) are among the variables in this study. All variables in this analysis, to calculate the degree of commitment of the Jakarta Islamic Index (JII). Thus the researcher's model:

$$
\begin{aligned}
& \Delta J I I_{t}=\alpha_{0}+\sum_{i=1}^{n} \alpha i \Delta J I I_{t-i}+\sum_{i=1}^{n} \beta i \Delta E R_{t-i}+\sum_{i=1}^{n} \gamma i \Delta X A U_{t-i}+ \\
& \sum_{i=1}^{n} \text { Si } \Delta D J I E U_{t-i}+\sum_{i=1}^{n} \theta i \Delta D J I M 25_{t-i}+\sum_{i=1}^{n} \mu i \Delta D J I M U S_{t-i}+ \\
& \sum_{i=1}^{n} \pi i \Delta D J I J P_{t-i}+\varepsilon_{t}+\text { CointEq }\left[\sum_{i=1}^{n} J I I_{t-i}+\sum_{i=1}^{n} E R_{t-i}+\right. \\
& \left.\sum_{i=1}^{n} D^{n I E U_{t-i}}+\sum_{i=1}^{n} D_{\text {JIM } 25_{t-i}+\sum_{i=1}^{n} D_{\text {JIMUS }}+i}+\sum_{i=1}^{n} D J I J P_{t-i}\right]
\end{aligned}
$$

Where:

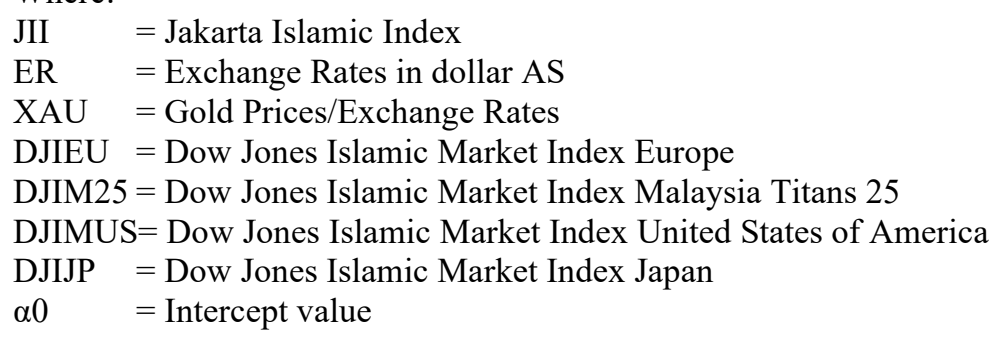


$\varepsilon \quad=$ Errors value

\subsection{Data Analysis Method}

This kind of research makes use of quantitative methods. The analytical tool used is the method of Vector Autoregression (VAR), if the data are stationary at the level. And if the data is not stationary at the stage then the Vector Error Correction Model (VECM) approach is used to do this. The data was analyzed with the applications E-views 10 and Ms-Excel 2010.

\subsection{Vector Autoregression (VAR)}

In 1980 the Vector Error Autoregressive was popularized by Christoper Sims. [18] in [19] VAR analysis model is an n-equation with n-variables, which are described through the lag value of the variable, and are (current and past values). Arsana (2005) in Firdaus [19], There are many uses for predictive VAR analysis, Causality Check, Impulse Response Function (IRF) and Forecast Error Variance Decomposition (FEVD). General VAR equation Enders (2004) in [19]:

$y_{t}=A_{0}+A_{1} y_{t-1}+A_{2} y_{t-2}+\cdots+A_{p} y_{t-p}+\varepsilon_{t}$

Where:

$y_{t}=$ Value vector $(n .1)$ contains $n$ variables in the model

$A_{0} \quad=$ Intercept vector with size $(n .1)$

$A_{1}=$ Coefficient matrix of value (n.n) and each $i=1,2, \ldots, \mathrm{p}$

$\varepsilon_{t} \quad=$ Valuable error vector $(n .1)$

\subsection{Vector Error Correction Model (VECM)}

Vector Error Correction Model (VECM) analysis is a form of refinement of VAR Enders (2004) in Firdaus[19]. Additional restrictions are made because there is no stationary data at the level level, then VECM analysis utilizes the cointegration restriction information into its specifications. VECM analysis is also a VAR design for non-stationary data, but there is a cointegration relationship. Firdaus[19] In VECM there is a speed of adjustment from short to long term. The VECM models generally are as follows:

$\Delta y_{t}=\mu_{0 x}+\mu_{1 x^{t}}+\prod_{x} y_{t-1}+\sum_{i=1}^{k-1} \tau i x \Delta y_{t-1}+\varepsilon_{t}$

Where:

$y_{t} \quad=$ Vectors contained in the variables analyzed in the study

$\mu_{0 x}=$ Intercept vector

$\mu_{1 x}=$ Regression coefficient vector

$\mathrm{t} \quad=$ Time trend

$\prod_{x}=\alpha_{x} \beta$ ' were $\mathrm{b}^{\prime}$ contains long-run cointegration equations

$y_{t-1}=$ Variable in-level

$\tau i x=$ Regression coefficient matrix

$k-1=$ Ordo VECM from VAR

$\varepsilon_{t} \quad=$ Error term 


\subsection{Stationary Test}

Stationary data is a time series data where time does not affect the avarage value, variant value and its covariance of all variables Juanda \& Junaidi [20]. A data is said to be stationary, if it tends to move around the average value. In testing stationary data you can use the Augmented Dickey Fuller (ADF) method. With the ADF method to find out if the data is stationary or not stationary, that is to compare the ADF t-statistic value to the critical value of Mac Kinnon. If the ADF t-statistic value exceeds the critical or critical value, the data is stationary. And not stationary in case the opposite happens. Following the model for the equation, namely:

$\Delta Y_{t}=a 0+\gamma Y_{t-1}+\sum_{i=1}^{z}+\beta \Delta Y_{t-1}+1+e t$

Where:

$\mathrm{Y} \quad=$ Variable Research

$\Delta Y_{t}=\mathrm{Y}_{\mathrm{t}}-\mathrm{Y}_{\mathrm{t}}-1$

$\mathrm{T} \quad=$ Time Trend

\subsection{Optimal Lag Test}

Optimal lag testing aims to determine the process time needed in a reaction between variables in the VAR analysis [19].

\subsection{VAR Stability Test}

VAR stability testing is needed, because if it is not stable then the estimation results on the model are less valid. It can be said that the VAR is stable if the inverse value of the root has a modulus value not exceeding one and is in the cricle unit.

\subsection{Cointegration Test}

This test was discovered by Engle et al. [21]. Cointegration can be interpreted in a study as a relationship between variables in the long run. And although there are variables that are not stationary, they will become stationary because of the linear combination between variables [20]. Cointegration test in the study used is Johansen's cointegration test. Where there are parameters to determine cointegration. Among them is if the value of t-statistics $>$ critical value, it can be said that there is cointegration.

\subsection{Causality Granger Test}

Engle et al.,[21] were the ones who discovered this Causality Test. This test is carried out in order to know the existence of a causal relationship between the dependent variable with its independent variable [19].

\subsection{Impulse Response Function (IRF)}

IRF method is a method used to see how endogenous variables react due to certain shocks. IRF aims to show the response or direction of motion, where a variable will respond when there is an effect of shocks from other variables. And if the variable is not affected, then it is a general 
shock that occurs [19].

\subsection{Forecast Error Variance Decomposition (FEVD)}

FEVD on VAR aims to find out the magnitude of each variable 's variance because of a variable that changes. The FEVD analysis is used to explain the relative importance of variables due to a shock in the VAR method [20].

\section{Results and Discussion}

\subsection{Stationarity Test}

Stationarity test is an initial step to test time series data. The stationarity of a data needs to be known before the next test. This test is done to determine the unit root among variables in a study. Using the Augmented Dickey-Fuller (ADF) test method the first level of testing is performed at the level. If it is not stationary at the level level, then the next test at the stationary test is first difference or second difference. As for the results of stationary testing at level, the following results are tabulated 3 .

Table 3. Stationarity Test Result on Level

\begin{tabular}{lccccc}
\hline \multirow{2}{*}{ Variables } & \multirow{2}{*}{ ADF Value } & \multicolumn{2}{c}{ Critical Value } & Mackinnon & \multirow{2}{*}{ Result } \\
\cline { 3 - 5 } JII & -2.835963 & -3.435074 & -2.863514 & -2.567870 & - \\
DJIEU & -1.545472 & -3.435074 & -2.863514 & -2.567870 & - \\
DJIJP & -1.376237 & -3.435078 & -2.863516 & -2.567871 & - \\
DJIMY25 & -2.920464 & -3.435074 & -2.863514 & -2.567870 & Stasioner \\
DJIMUS & -0.689339 & -3.435074 & -2.863514 & -2.567870 & - \\
RATES & -2.468787 & -3.435078 & -2.863516 & -2.567871 & - \\
GOLD & -1.012227 & -3.435074 & -2.863514 & -2.567870 & - \\
\hline \multicolumn{5}{c}{ Source: }
\end{tabular}

Source: data processing by Eviews

Based on the stationarity test at the above level, it was concluded that only DJIMY25 variables were stationary at 5\% significance level. In order to find the results that are stationary then proceed to the 1 st difference stationarity test. Table 4 found that all the variables on the 1 st difference were stationary.

Table 4. Stationarity Test Result on $1^{\text {st }}$ difference

\begin{tabular}{cccccc}
\hline \multirow{2}{*}{ Variables } & \multirow{2}{*}{ ADF Value } & \multicolumn{3}{c}{ Critical Value Mackinnon } & \multirow{2}{*}{ Result } \\
\cline { 3 - 5 } & & $\mathbf{1 \%}$ & $\mathbf{5 \%}$ & $\mathbf{1 0 \%}$ & \\
\hline$\Delta$ JII & -36.91029 & -3.435078 & -2.863516 & -2.567871 & Stasioner \\
$\Delta$ DJIEU & -36.00119 & -3.435078 & -2.863516 & -2.567871 & Stasioner \\
$\Delta$ DJIJP & -43.34368 & -3.435078 & -2.863516 & -2.567871 & Stasioner \\
$\Delta$ DJIMY25 & -34.08436 & -3.435078 & -2.863516 & -2.567871 & Stasioner \\
$\Delta$ DJIMUS & -36.35896 & -3.435078 & -2.863516 & -2.567871 & Stasioner \\
$\Delta$ RATES & -32.09947 & -3.435078 & -2.863516 & -2.567871 & Stasioner \\
$\Delta$ GOLD & -38.14576 & -3.435078 & -2.863516 & -2.567871 & Stasioner \\
\hline \multicolumn{5}{c}{ Sounnnnnn }
\end{tabular}

Source: data processing by Eviews 


\subsection{Lag Optimal}

In analyzing data preformance in the VAR method there are often problems with autokoleration. Therefore, it can be overcome by determining the optimum lag. Determine the optimal lag based on the value of akaike criteria. and the optimal lag test results can be seen in table 5. Based on the test results, the optimal lag value is in the second lag.

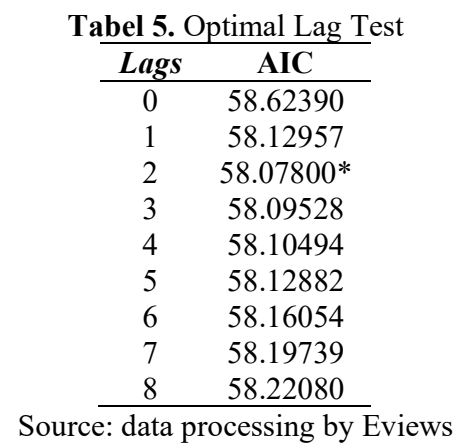

\subsection{Stability VAR Test}

The VAR model is called stable if all the root values in the VAR with modulus values do not exceed one and are inside the unit circle. The modulus value in this study ranged from 0.193518 - 0.425148. Based on these results it can be concluded that the VAR model is stable. In Appendix 3 the complete results of the VAR stability test.

\subsection{Cointegration Test}

In stationary testing the 1st difference level all variables are stationary (Appendix 1), then the cointegration test can be done with the Johansen Cointegration Test.

Table 6. Cointegration Test Result

\begin{tabular}{cccc}
\multicolumn{4}{c}{ Table 6. Cointegration Test Result } \\
\hline $\begin{array}{c}\text { Hypothesized } \\
\text { No.of CE(s) }\end{array}$ & Eigenvalues & T-Statistic & $\begin{array}{c}\text { 5 Persent Critical } \\
\text { Values }\end{array}$ \\
\hline None * & 0.528518 & 4381.522 & 111.7805 \\
At most 1 * & 0.467012 & 3386.792 & 83.93712 \\
At most 2* & 0.374449 & 2554.287 & 60.06141 \\
At most 3 & 0.346891 & 1933.638 & 40.17493 \\
At most 4 & 0.322007 & 1370.025 & 24.27596 \\
At most 5 * & 0.289898 & 855.8833 & 12.32090 \\
At most 6 * & 0.262566 & 402.9582 & 4.129906 \\
\hline \multicolumn{4}{c}{ Information : *shows significant at 5\% } \\
Source: data processing by Eviews
\end{tabular}

Table 6 explains that there is a maximum of cointegration of six cointegration equations from seven indications. It can be seen that the T-statistic value> Critical Value. Because it shows the existence of cointeragration, the VECM model continues. 


\subsection{Granger Causality Test}

From the results of the stationary granger causality test the 1st difference level there is causality between variables. The test level used is at the real level of 0.05 and the lag length is two. The lag that is used is in accordance with the previous optimal lag testing. The real level of 0.05 can be seen in the probability value. If the probability value exceeds 0.05 , it can be concluded that there is no causal relationship between variables. And if the probability value is less than 0.05 then there is a causal relationship between variables (rejecting $\mathrm{H} 0$ ).

The hypothesis is:

H0: The dependent variable is not significantly affected by the independent variable.

H1: The dependent variable is significantly influenced by the independent variable.

Table 7. Granger Causality Test Result on $1^{\text {st }}$ difference

\begin{tabular}{cc}
\hline Null Hypothesis & Probability \\
\hline$\Delta$ DJIEU doesn't Granger Cause $\Delta \mathrm{JII}$ & $1 . \mathrm{E}-10^{*}$ \\
$\Delta \mathrm{JII}$ doesn't Granger Cause $\Delta \mathrm{DJIEU}$ & 0.4325 \\
$\Delta \mathrm{DJIP}$ doesn't Granger Cause $\Delta \mathrm{JII}$ & 0.8746 \\
$\Delta \mathrm{JII}$ doesn't Granger Cause $\Delta \mathrm{DJIP}$ & $0.0019^{*}$ \\
$\Delta \mathrm{DJIM} 25$ doesn't Granger Cause $\Delta \mathrm{JII}$ & 0.3603 \\
$\Delta \mathrm{JII}$ doesn't Granger Cause $\Delta \mathrm{DJIM} 25$ & 0.4612 \\
$\Delta \mathrm{DJIMUS}$ doesn't Granger Cause $\Delta \mathrm{JII}$ & $3 . \mathrm{E}-22^{*}$ \\
$\Delta \mathrm{JII}$ doesn'tt Granger Cause $\Delta \mathrm{DJIMUS}$ & 0.5063 \\
$\Delta \mathrm{RATES}$ doesn't Granger Cause $\Delta \mathrm{JII}$ & 0.0589 \\
$\Delta \mathrm{JII}$ doesn't Granger Cause $\Delta \mathrm{RATES}$ & 0.9540 \\
$\Delta \mathrm{GOLD}$ doesn't Granger Cause $\Delta \mathrm{JII}$ & $0.0002^{*}$ \\
$\Delta \mathrm{JII}$ doesn't Granger Cause $\Delta \mathrm{GOLD}$ & 0.8821 \\
\hline \multicolumn{2}{c}{ Information : *shows significant at $5 \%$} \\
Source: data processing by Eviews
\end{tabular}

Based on the results of the granger causality test for the 1st difference in table 8 above, it can be seen that the DJIEU, DJIMUS, Gold and JII have a one-way causality relationship. This means that DJIEU, DJIMUS and Gold affect JII positively and significantly. Every change in DJIEU, DJIMUS and Gold will be followed by changes in JII positively. However, any changes in JII cannot positively affect DJIEU, DJIMUS and Gold significantly.

JII affects DJIJP positively and significantly. This means that every change in JII will be followed by a positive change in DJIJP. However, any changes to the DJIJP cannot positively affect the JII significantly. The exchange rate does not have a causal relationship with JII. This means that the exchange rate cannot positively influence the JII significantly. Likewise, JII cannot significantly affect the exchange rate positively.

\subsection{Vector Error Corretion Model (VECM)}

A study with this model, VECM estimation aims to determine the long-term and short-term relationships.

Table 8. VECM Estimation Result

\begin{tabular}{ccc}
\hline \multicolumn{3}{c}{ Long Term } \\
\hline Variable & Coefficient & T-Statistic \\
\hline$\Delta($ DJIEU(-1)) & -5.279649 & {$[-7.20847]^{*}$} \\
$\Delta($ DJIJP(-1)) & 30.94534 & {$[25.5689]^{*}$} \\
$\Delta($ DJIM25(-1)) & 4.982973 & {$[1.93266]$} \\
\hline
\end{tabular}




\begin{tabular}{|c|c|c|}
\hline$\Delta$ (DJIMUS(-1)) & -8.171409 & {$[-14.7273]^{*}$} \\
\hline$\Delta($ RATES(-1)) & -0.392863 & {$[-1.32601]$} \\
\hline$\Delta(\mathrm{GOLD}(-1))$ & -5.029663 & {$[-3.29563]^{*}$} \\
\hline \multicolumn{3}{|c|}{ Short Term } \\
\hline Variable & Coefficient & T-Statistic \\
\hline CointEq1 & -0.002514 & {$[-2.46319]$} \\
\hline$\Delta(\mathrm{JII}(-1), 2)$ & -0.649144 & {$[-22.6486]$} \\
\hline$\Delta(\mathrm{JII}(-2), 2)$ & -0.304992 & {$[-10.7294]$} \\
\hline$\Delta(\operatorname{DJIEU}(-1), 2)$ & 0.008151 & [ 0.92107$]$ \\
\hline$\Delta(\mathrm{DJIEU}(-2), 2)$ & 0.014250 & [ 1.75952$]$ \\
\hline$\Delta($ DJIJP(-1),2) & 0.056992 & {$[2.39805]^{*}$} \\
\hline$\Delta($ DJIJP(-2),2) & 0.024426 & {$[1.74835]$} \\
\hline$\Delta($ DJIM25(-1),2) & 0.003449 & [ 0.09319$]$ \\
\hline$\Delta($ DJIM25(-2),2) & 0.031973 & {$[0.87125]$} \\
\hline$\Delta$ (DJIMUS(-1),2) & 0.027259 & {$[3.12040]^{*}$} \\
\hline$\Delta$ (DJIMUS(-2),2) & -0.002127 & {$[-0.31140]$} \\
\hline$\Delta(\operatorname{RATES}(-1), 2)$ & -0.003307 & {$[-0.75156]$} \\
\hline$\Delta(\operatorname{RATES}(-2), 2)$ & 0.004661 & [ 1.07818$]$ \\
\hline$\Delta(\operatorname{GOLD}(-1), 2)$ & 0.055009 & {$[2.77101]^{*}$} \\
\hline$\Delta(\operatorname{GOLD}(-2), 2)$ & -0.010794 & {$[-0.54202]$} \\
\hline
\end{tabular}

The VECM estimation results in the short term show that the DJIJP has a positive effect on JII, the first lag is significant at 0.056992 . If there was an increase in the previous day's DJIJP by one percent, the JII would now increase by 0.057 percent. IMUS has a positive effect on JII, the first lag is significant at 0.027259 . If the previous day's IMUS increased by one percent, then JII now also increases by 0.027 percent. Gold has a positive effect on JII, the first lag is significant at 0.055009 . If Gold rose the previous day by one percent, JII is now up by 0.055 percent.

In the long run, the VECM estimate results that the exchange rate has no significant negative effect on JII. This means that an increase in the exchange rate of one percent can reduce JII by 0.39 percent. This is in accordance with the research of Beik \& Fatmawati [1], Ardana \& Maya [11] which shows that exchange rates and share prices are negatively related, this happens because of the large capital outflow by foreign investors. However, the effect on JII is not significant, this can happen because the proportion of foreign investors' portfolios in stocks in the JII index is smaller.

Gold has a significant negative effect on JII, which means that a one percent increase in gold can cause a decrease in JII by as much as 5.03 percent. The results are not in accordance with Utoyo \& Riduwan [13], Agestiani \& Sutanto [14] where gold has a positive effect. However, according to Setiawan's research [15], gold has a negative, insignificant effect. This happens because gold is a safer choice for investors (save haven) in the long term when the stock market is experiencing a crash or is in a downtrend.

DJIJP has a significant positive effect on JII, which means that the DJIJP increases by one percent, JII can increase by 30.95 percent. This is different from the research of Beik \& Fatmawati [1], Ardana \& Maya [11] stated that DJIJP has a negative and significant effect. DJIEU has a significant negative effect on JII, which means that an increase in DJIEU by one percent can reduce JII by 5.28 percent. This result is different from the research Beik \& Fatmawati [1] that DJIEU has a significant positive effect on JII.

The DJIM25 had no significant positive effect, meaning that the one percent increase in the DJIM25 was followed by an increase in JII of 4.98 percent. This is in accordance with the 
results of research by Beik \& Fatmawati [1], Oktaviani [17] stated that DJIM25 has a positive but significant effect. IMUS has a significant negative effect on JII, which means that an increase in IMUS by one percent is followed by a decrease in JII by 8.17 percent. These results are not in accordance with Ardana \& Maya [11] where IMUS has a positive effect on JII.

\subsection{Impulse Response Function (IRF)}

This analysis is the stage carried out to see the response to endogenous variables due to certain shocks. In this study will find out the effect of JII variables on DJIEU, DJIJP, DJIMY25, IMUS, Exchange Rate, and Gold. From the picture shows that the response of JII if given an impulse from JII itself, DJIEU, DJIJP, DJIMY25, IMUS, Exchange and Gold.

Responsed of D(JAKARTA) to D(JAKARTA)

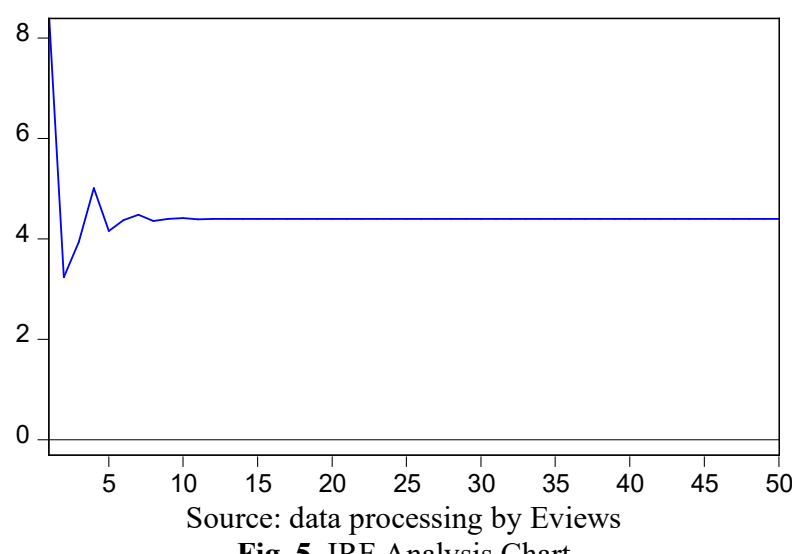

Fig. 5. IRF Analysis Chart

JII positive response if imposed by JII itself. In the first period down then fluctuate and begin to stabilize in a positive position from period 18 to period 50 .

Responsed of D(JAKARTA) to D(EROPA)

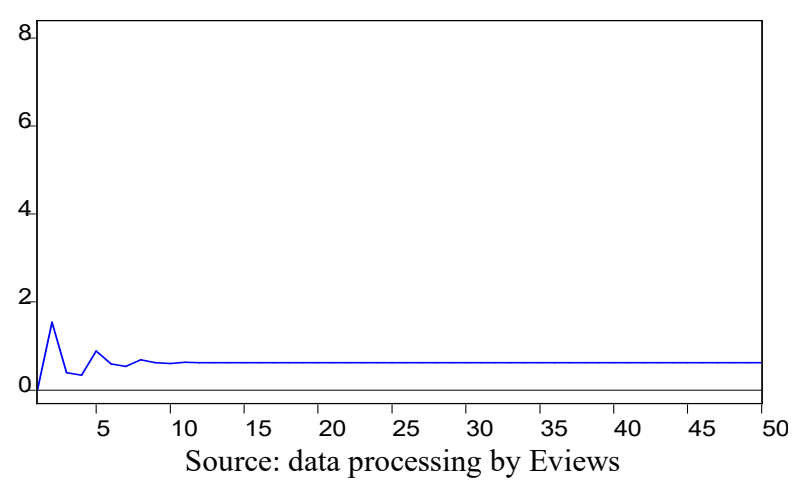

In the first period it rises then fluctuates and begins to stabilize in a positive position from period 11 to period 50 . 
Responsed of $\mathrm{D}$ (JAKARTA) to $\mathrm{D}(\mathrm{US})$

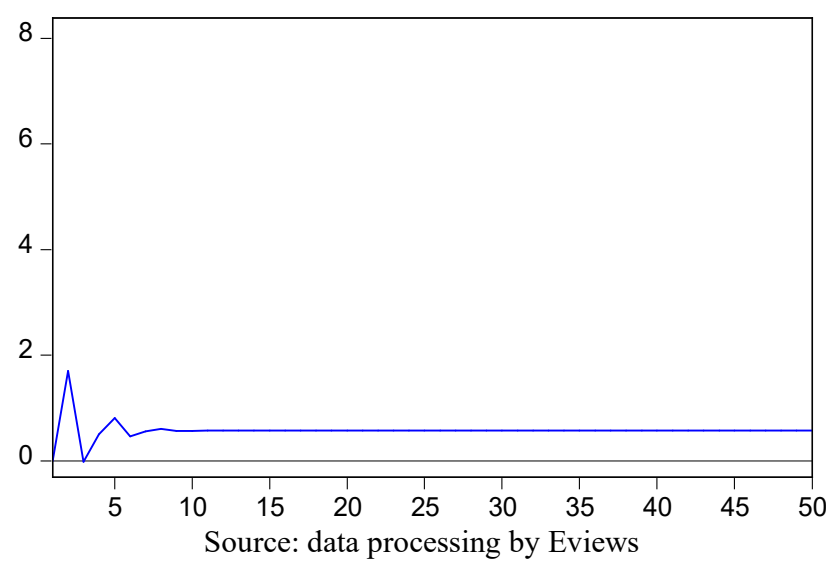

JII positive response if impulse IMUS. In the first period, it goes up and then it goes down negatively, but it goes up in positive fluctuations. And began to stabilize in a positive position from period 13 to period 50 .

Responsed of D(JAKARTA) to D(JEPANG)

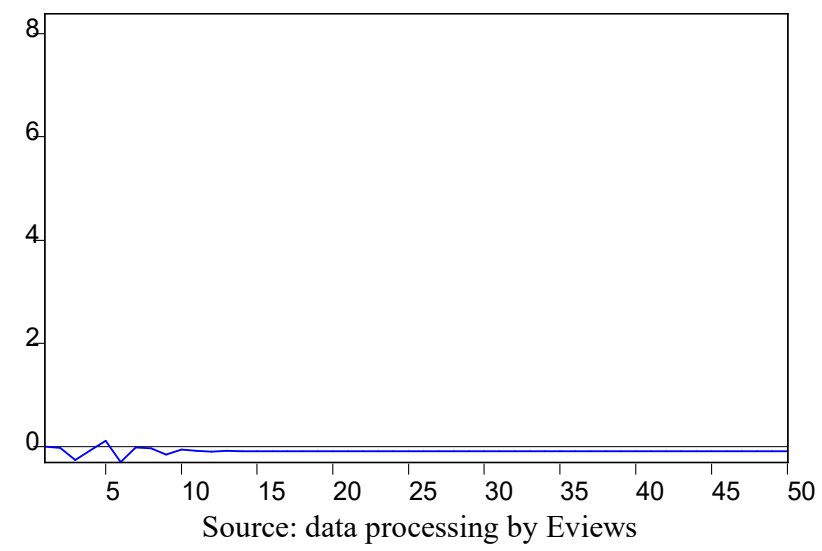

A negative response if JII is impulse by DJIJP. In the first period negative down then rose positive, but down the negative position in the negative position. And began to stabilize in negative positions from period 10 to period 50 . 
Responsed of D(JAKARTA) to D(MALAYSIA)

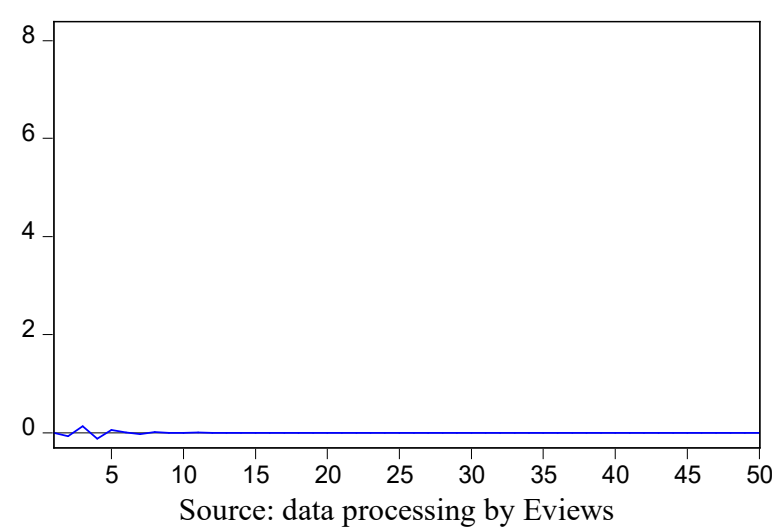

JII negative response if it is impulse DJIMY25. In the first period down then fluctuate. And began to stabilize in negative positions from period 9 to period 50 .

Responsed of D(JAKARTA) to D(KURS)

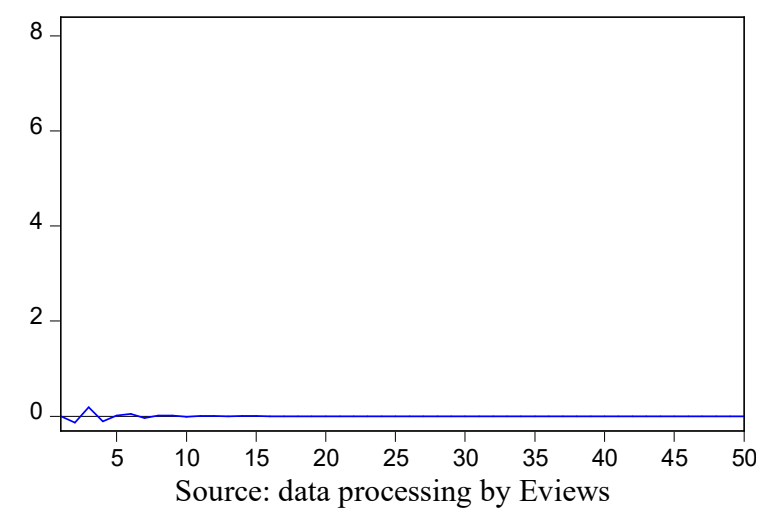

JII negative response if the exchange rate is impulse. In the first period down then fluctuate. And began to stabilize in negative positions from period 9 to period 50 .

Responsed of D(JAKARTA) to D(EMAS)

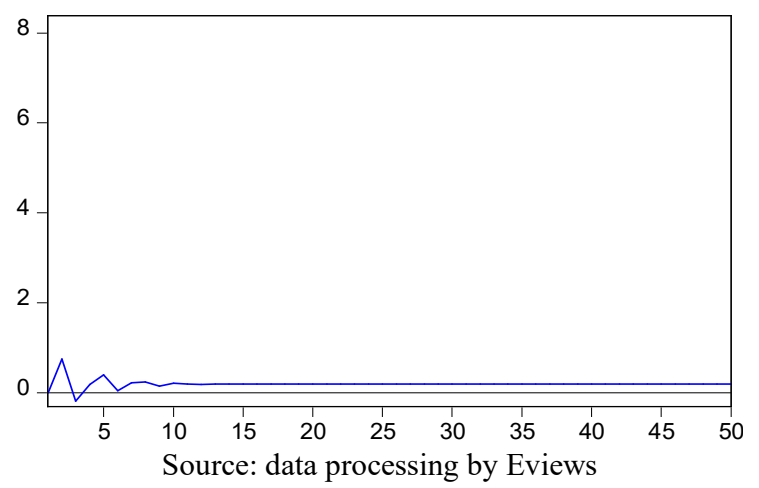


JII positive response if impulse Gold. In the first period, it goes up and then it goes down negatively, but it goes up in positive fluctuations. And began to stabilize in a positive position from period 10 to period 50. Based on the results of the IRF analysis above, JII's response will be positive towards JII, DJIEU, IMUS and Gold if impulse. stabilized in periods of 10 to 18 over 50 daily periods. Then JII's response will be negative for DJIJP, DJIMY25 and the exchange rate when impulse. And it starts to stabilize in periods of 9 to 10 for 50 daily periods.

\subsection{Forecasting Error of Variance Decomposition (FEVD)}

In a study using the VAR model, FEVD analysis was performed to predict the contribution magnitude of each variable. Because in the VAR model system there are changes in certain variables.

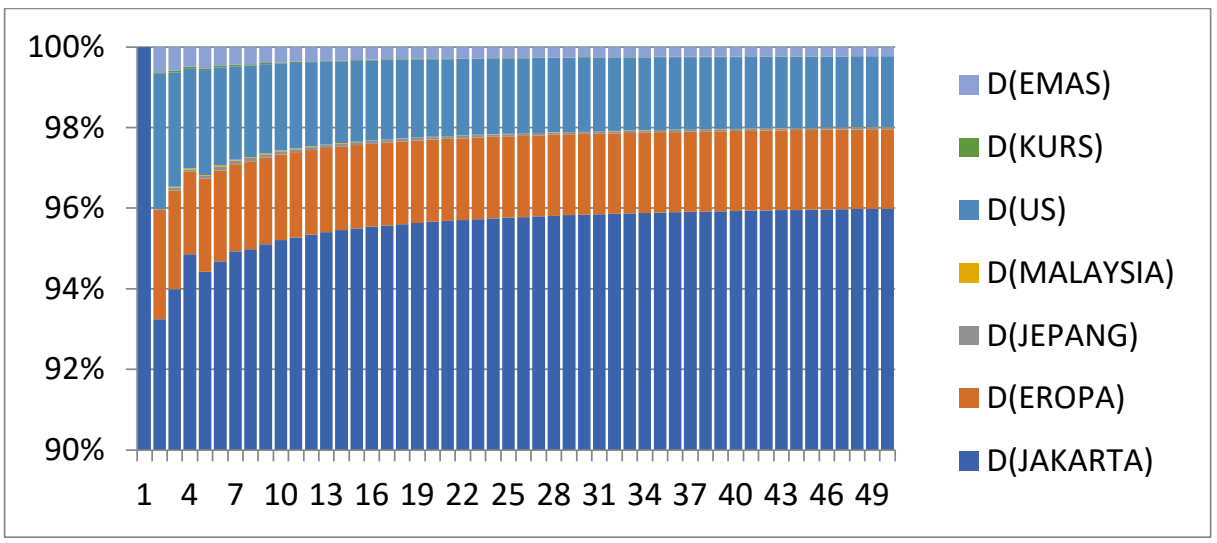

Source: data processing by Eviews

Fig. 6. Forecasting Error of Variance Decomposition (FEVD)

From the results of the FEVD analysis on JII shows the results, namely in the first period in 50 daily periods, JII is 100 percent influenced by JII itself. Until the 50th period, JII had an effect of 96 percent. Then IMUS affects JII by 3.36 percent, DJIEU by 2.72 percent, Gold by 0.65 percent, DJIJP by 0.10 percent, Exchange rate by 0.052 percent and DJIMY 25 by 0.028 percent.

\section{Conclusion}

The long-term results of the VECM analysis DJIEU have a significant adverse effect on JII. IMUS has a marked negative effect on JII. DJIJP has considerable positive effects on JII. DJIMY 25 does have a negligible positive effect on JII. The exchange rate has minor adverse effects on JII. Gold has a pronounced negative impact on JII.

The results of the VECM analysis have no significant positive effect on JII in the short-term DJIEU index. The IMUS index has a considerable positive effect on JII. The DJIJP index has a considerable positive effect on JII. The index DJIMY25 has no significant positive impact on JII. The exchange rate does not have any major adverse impact on JII. And Gold has an significant positive influence on JII.

The results of the IRF indicate that JII fluctuates with a shock to achieve stability. After 
duration 14, the average time required to achieve stability is. The FEVD study effects of all variables then have an effect on JII. The first JII period is influenced by JII 100.0 percent. JII had an impact of 96 percent until the 50th period. IMUS then affects JII by 3.36\%, DJIEU by $2.72 \%$, Gold by $0.65 \%$, DJIJP by $0.10 \%$, Exchange rate by $0.052 \%$ and DJIMY 25 by $0.028 \%$.

\section{References}

[1] I. S. Beik and S. W. Fatmawati, "Pengaruh Indeks Harga Saham Syariah Internasional dan Variabel Makro Ekonomi Terhadap Jakarta Islamic Index," no. April 2014, pp. 155 178, 2014.

[2] E. Tandelilin, Portofolio dan Investasi Teori dan Aplikasi, Pertama. Yogyakarta: Kanisius, 2010.

[3] B. Sudiyatno and C. Nuswandhari, "Peran Beberapa Indikator Ekonomi dalam Mempengaruhi Risiko Sistematis Perusahaan Manufaktur di Bursa Efek Indonesia Jakarta," Din. Keuang. dan Perbank., vol. 1, no. 2, pp. 66-81, 2009.

[4] B. News, "US-China trade war: New tariffs come into force," BBC News, 2018.

[5] A. Walker and D. Palumbo, "Argentina - the crisis in six charts," BBC News, 2018.

[6] B. News, "Turkey's economy slides into recession," BBC News, 2019.

[7] J. A. R. Tan, Contagion effects during the Asian financial crisis: Some evidence from stock price data. Citeseer, 1998.

[8] A. Haryogo, "Pengaruh Nilai Tukar dan Indeks Dow Jones Terhadap Composite Index di Bursa Efek Indonesia," Finesta, vol. 1, no. 1, pp. 1-6, 2013.

[9] J. K. M. Kuwornu, N. Resources, and V. Owusu-nantwi, "Macroeconomic Variables and Stock Market Returns : Full Information Macroeconomic Variables and Stock Market Returns : Full Information Maximum Likelihood Estimation," no. August 2017, 2011.

[10] M. Hussin, F. Muhammad, M. F. Abu, and S. A. Awang, "Macroeconomic Variables and Malaysian Islamic Stock Market : A Time Series Analysis," vol. 3, no. 4, pp. 1-13, 2012.

[11] Y. Ardana and S. Maya, "Determinasi Faktor Fundamental Makroekonomi dan Indeks Harga Saham Syariah Internasional terhadap Indeks Harga Saham Syariah Indonesia," vol. 14, no. 1, pp. 1-15, 2019.

[12] M. Asmy, W. Rohilina, A. Hassama, and M. Fouad, "Effects of Macroeconomic Variables on Stock Prices in Malaysia: An Approach of Error Correction Model," no. September, 2009.

[13] N. ndari Utoyo and A. Riduwan, "Pengaruh tingkat inflasi, suku bunga, harga emas dunia, dan kurs rupiah pada jii," vol. 5, no. c, 2016.

[14] A. Agestiani and H. A. Sutanto, "Pengaruh indikator makro dan harga emas dunia terhadap indeks harga saham syariah (jakarta islamic index)," vol. 1, no. 1, pp. 26-38, 2019.

[15] M. asri Setiawan, "Analisis Pengaruh Dow Jones Islamic Market Asia/Pacific Ex-Japan (DJIP2), Dow Jones Arabia Titans 50 (DJARB50), Harga Emas Dunia, dan Nilai Kurs Terhadap JII Tahun 2016-2018,” vol. 4, no. 1, pp. 64-78, 2019.

[16] I. S. Beik and W. Wardana, "The Relationship Between Jakarta Islamic Index and Other Selected Markets :," no. 2, pp. 100-109, 2011.

[17] R. F. Oktaviani, "Index Harga Saham Islamic Internasional terhadap Jakarta Islamic Index," vol. 6, no. 1, pp. 1-15, 2017.

[18] J. H. Stock, M. W. Watson, J. F. Kennedy, and P. Affairs, "Vector Autoregressions," vol. 
2001, no. March, 2001.

[19] M. Firdaus, Aplikasi Ekonometrika Untuk Data Panel dan Time Series. Bogor (ID): IPB Press, 2011.

[20] B. Juanda and Junaidi, Ekonometrika Deret Waktu Teori dan Aplikasi. Bogor (ID): IPB Press, 2012.

[21] R. F. Engle, C. W. J. Granger, and N. Mar, "Co-Integration and Error Correction : Representation, Estimation, and Testing,” vol. 55, no. 2, pp. 251-276, 1987. 